To cite: $M$ Hailbronner 'Laws in conflict: The relationship between human rights and international humanitarian law under the African Charter on Human and Peoples' Rights' (2016) 16 African Human Rights Law Journal 339-364

http://dx.doi.org/10.17159/1996-2096/2016/v16n2a2

\title{
Laws in conflict: The relationship between human rights and international humanitarian law under the African Charter on Human and Peoples' Rights
}

\author{
Michaela Hailbronner* \\ Humboldt Research Fellow, Institute for International and Comparative Law, \\ University of Pretoria, South Africa
}

\begin{abstract}
Summary
Most armed conflicts today take place in Africa and it is increasingly African actors who are engaged in peacekeeping on the continent, yet scholarly writing on the regulation of these conflicts lags behind. One area where this is particularly true concerns sanctioning violations of international humanitarian law. This has long been difficult, given the tendency of domestic systems to close ranks and insulate their citizens from legal action. To provide at least some forum for justice in this situation, regional human rights bodies increasingly deal with rights violations even in situations of war, raising questions about their mandate and the relationship between human rights and humanitarian law. In the European and American context, these questions have already been the subject of considerable academic writing, but the same is not true for Africa. This article seeks to fill this gap. It first situates the existing approach of the major pan-African human rights institutions to international humanitarian law within the broader global debate. As a second step, it argues that an interpretive approach which takes international humanitarian law into consideration when interpreting rights in the African Charter provides the best approach to this question in the African context.
\end{abstract}

Key words: African Charter; peacekeeping; humanitarian law; human rights law; armed conflict

LLM (Yale) JSD (Yale); mhailbronner@gmail.com. I am grateful to James Fowkes, Magnus Killander, Jan Kleffner, Frans Viljoen, Erika de Wet and the anonymous reviewers for comments on earlier drafts of the article. 


\section{Introduction}

International humanitarian law has long lacked adequate means of sanctioning violations. Military mechanisms for punishing wrongdoers have often proved weak for lack of political willingness, and domestic courts have displayed a similar reluctance or grappled with other difficulties. ${ }^{1}$ As a result, it has increasingly fallen to international courts or quasi-judicial bodies to address violations of international humanitarian law - be it within the realm of international criminal responsibility or human rights. Regional human rights bodies have dealt with this challenge in different ways. Some, such as the European Court of Human Rights (European Court), have approached international humanitarian law with caution and focused primarily on their human rights mandate (at least until recently), ${ }^{2}$ whereas others, such as the Inter-American Commission on Human Rights (InterAmerican Commission), have been more willing to engage with international humanitarian law and sometimes even applied it directly. ${ }^{3}$

The African human rights system and its capacity to deal with violations of international humanitarian law have thus far received little scholarly attention. ${ }^{4}$ This is perhaps not surprising, considering the comparative dearth of legal scholarship on African issues. Yet, Africa is the region where most contemporary armed conflicts arise,

1 For more, see $X$ Philippe 'Sanctions for violations of international humanitarian law: The problem of the division of competences between national authorities and between national and international authorities' (2008) 90 International Review of the Red Cross 359.

2 This is mainly because the European Court in the past required states to make an explicit derogation from the Convention, without which it would judge states against the 'normal legal background'. See eg Isayeva $v$ Russia App 57950/00 EurCtHR (2005) para 191. For a detailed overview, see also K Oellers-Frahm 'A regional perspective on the convergence and conflicts of human rights and international humanitarian law in military operations: The European Court of Human Rights' in E de Wet \& J Kleffner (eds) Convergence and conflicts of human rights and international humanitarian law in military operations (2014) 333. The European Court's decision in Hassan v The United Kingdom ECHR 29750/09 (2014) now changes this somewhat; for details see below.

3 See Abella $v$ Argentina Case 11.137, IAm Comm of HR, OEA/Ser.L.N/1.95 Doc 7 (1997) which differs, however, from the Inter-American Court's approach in later cases, which is nevertheless still comparatively IHL-friendly. See eg BamacaVelasquez v Guatemala, IAm Comm of HR (ser C) No 70 (25 November 2000). For an overview of the developments in the Inter-American system only, see D Shelton 'Humanitarian law in the Inter-American human rights system' in De Wet \& Kleffner (n 2 above); S Tabak 'Armed conflict and the Inter-American human rights system: Application or interpretation of international humanitarian law?' in D jinks et al (eds) Applying international humanitarian law in judicial and quasi-judicial bodies: International and domestic aspects (2014) 219.

4 See $F$ Viljoen 'The relationship between international human rights and humanitarian law in the African human rights system: An institutional approach' in De Wet \& Kleffner (n 2 above); and for a very short treatment, $L$ van den Herik \& $\mathrm{H}$ Duffy 'Human rights bodies and international humanitarian law: Common but differentiated approaches' forthcoming in C Buckley et al (eds) The harmonisation of human rights law (2014). 
and African states are also at the forefront of contemporary peacekeeping operations, frequently under the common roof of African regional organisations, such as the Economic Community of West African States (ECOWAS) and the African Union (AU). ${ }^{5}$ As many domestic African courts still have to establish their independence and public authority, ${ }^{6}$ here, more than elsewhere, regional bodies can play an important role in sanctioning violations of international humanitarian law.

The article focuses on the most important pan-African institutions charged with the protection of human rights ${ }^{\prime}$ and their capacity to address violations of humanitarian law. These are the African Commission on Human and Peoples' Rights (African Commission) and the African Court on Human and Peoples' Rights (African Court), both of which are mandated to apply, first and foremost, the African Charter on Human and Peoples' Rights (African Charter). I begin by setting out the position of these two bodies on international humanitarian law against the broader comparative background of the current debate on this topic. As will be seen, both the African Commission and the African Court are only just beginning to address questions of the application of humanitarian law, and even when they do so, it is often in vague and unclear terms, leaving more questions and problems open than answered. This raises the question, which is addressed in the second part of the article, namely, what a good approach to the relationship between international humanitarian law and African Charter rights may look like in the African context. Given that the African Charter, unlike other regional human rights instruments, such as the European Convention on Human Rights (European Convention), often formulates rights very broadly, it is argued that an interpretive approach that reads international humanitarian law into human rights provisions is here, perhaps unlike elsewhere, both feasible and convincing. Limitation clauses and a proportionality analysis can help minimise conflicts between human rights and humanitarian law within this framework - making this overall a sound approach to the relationship between international humanitarian law and human rights in the African context.

5 See also the AU's favourable stance on humanitarian interventions as expressed in art 4(h) of the AU's Constitutive Act; for more on regional developments, E de Wet 'The evolving role of ECOWAS and the SADC in peace operations: A challenge to the primacy of the United Nations Security Council in matters of peace and security?' (2014) 27 Leiden Journal of International. Law 353; and E de Wet 'Regional organisations and arrangements and their relationship with the United Nations: The case of the African Union' in M Weller et al (eds) The Oxford handbook on the use of force (2015) 314.

6 For an overview, see C Fombad 'Chapters 2 and 3' in C Fombad (ed) Stellenbosch handbooks of African constitutionalism Volume 1: Separation of powers (forthcoming).

7 I do not address the African Committee of Experts on the Rights and Welfare of the Child here since it deals with a more specific subject matter; for this, see Viljoen (n 4 above). 


\section{Obstacles and approaches to the application of humanitarian law by human rights bodies: State of the debate and African responses}

Today, a number of earlier obstacles to the application of international humanitarian law by human rights bodies have fallen away. In particular, it is now broadly established that human rights do not generally cease to be applicable in armed conflicts. The International Court of Justice (ICJ) has confirmed this with respect to the International Covenant on Civil and Political Rights (ICCPR), ${ }^{8}$ as have other bodies in Europe with regard to the European Convention ${ }^{9}$ and in Latin-America ${ }^{10}$ with regard to the American Convention on Human Rights (American Convention). ${ }^{11}$

Similarly, it has become largely accepted that international human rights apply extra-territorially in situations where states have jurisdiction over foreign territory or persons by exercising effective control over them. ${ }^{12}$ While there still is much debate over what exactly constitutes effective control, the general principle, at least, is widely recognised today, even though some states, such as the United States, still partly resist the extra-territorial application of human rights. ${ }^{13}$ Without much ado, the African Commission has assumed the extra-territorial applicability of the African Charter in its $D R C$ decision in a situation where the respondents had occupied the territory of another member state. ${ }^{14}$ Moreover, even some domestic African courts, such as the South African Constitutional Court, have applied domestic human rights provisions extra-territorially even though they are likely to be more deferent in reviewing foreign policy decisions. ${ }^{15}$

What remains contested, however, is the precise relationship between human rights and international humanitarian law in

8 See eg Legal Consequences of the Construction of a Wall in the Occupied Palestinian Territory 2004 ICJ 136 (9 July); Democratic Republic of Congo v Uganda 2005 ICJ 168, TT 216-20 (19 December).

9 See eg Al-Jedda $v$ The United Kingdom ECHR 27021/08 (2011).

10 See eg Abella (n 3 above).

11 Van den Herik \& Duffy (n 4 above).

12 See eg the ICJ's jurisprudence in Legal Consequences for States of the Continued Presence of South Africa in Namibia 1971 ICJ 16, 54 (21 June) and Construction of a Wall (n 8 above).

13 US resistance to the extra-territorial application of human rights has, however, been somewhat weakening under the Obama administration, eg on torture; Editorial Board 'Close the overseas torture loophole: President Obama and the Convention Against Torture' New York Times 20 October 2014.

14 Democratic Republic of the Congo v Burundi, Rwanda and Uganda (2004) AHRLR 19 (ACHPR 2003).

15 Kaunda $v$ President of the Republic of South Africa 2005 (4) SA 235 (CC). In the recent Zimbabwean torture case, the South African Constitutional Court emphasised that extra-territoriality does not in principle preclude the duty of the police to investigate crimes committed elsewhere; National Commissioner of The South African Police Service $v$ Southern African Human Rights Litigation Centre \& Another 2015 (1) SA 315 (CC). 
particular cases, even if both regimes generally apply. This question has arisen particularly in human rights courts and quasi-judicial bodies, which have addressed this question in different ways. Most often, they have sought to avoid finding conflicts between the two bodies of law, sometimes with problematic results that have been widely criticised by the academic community (more below). How to deal with conflicts between international humanitarian law and human rights, therefore, remains contested among governments, scholars and courts, and the available case law is often less than consistent. Following Hathaway et al, it is useful to distinguish between three different approaches: one in which international humanitarian law prevails in cases of conflicts between the two bodies of law; another in which human rights prevail; and, finally, one in which the more specific law in the particular context and question at hand applies. ${ }^{16}$

The advantage of the first approach that resolves conflicts between the two regimes in favour of international humanitarian law is first and foremost its clarity: Whenever there is an armed conflict and human rights and international humanitarian law conflict, international humanitarian law is supreme. ${ }^{17}$ The ICJ's Nuclear Weapons decision has been read by some this way, even though the wording is ambiguous: ${ }^{18}$

In principle, the right not arbitrarily to be deprived of one's life applies also in hostilities. The test of what is an arbitrary deprivation of life, however, then falls to be determined by the applicable lex specialis, namely, the law applicable in armed conflict, which is designed to regulate the conduct of hostilities. Thus, whether a particular loss of life, through the use of a certain weapon in warfare, is to be considered an arbitrary deprivation of life contrary to article 6 of the Covenant, can only be decided by reference to the law applicable in armed conflict and not deduced from the terms of the Covenant itself.

In its later $D R C$ decision, however, the ICJ took a different, even less clear, position by avoiding addressing the possibility of conflict between the two bodies of law at all. ${ }^{19}$

Not surprisingly, it is mostly human rights bodies that have taken the second pro-human rights approach, based on the argument that their primary mandate, after all, is the protection of the respective

16 O Hathaway et al 'Which law governs during armed conflict? The relationship between international humanitarian law and human rights law' (2011) 96 Minnesota Law Review 1883.

17 As Hathaway et al (n 16 above 1906-1908) note, the Australian government has, among others, adopted this approach.

18 Legality of the Threat or Use of Nuclear Weapons 1996 ICJ 226 para 25 (8 July) (Advisory Opinion).

19 See $D R C$ (n 14 above) para 216. 
human rights instruments and that they have to observe the limits of their own jurisdiction. ${ }^{20}$ To what degree they may take international humanitarian law into account depends on whether the respective treaties refer to other sources of international law and whether they include particular derogation clauses allowing for the suspension of human rights in favour of international humanitarian law. If there are no such references to other international law, article 31(3)(c) of the Vienna Convention on the Law of Treaties (Vienna Convention) at least sets out that other international rules binding on the parties are part of the relevant context to be taken into account when interpreting a treaty. This suggests that international humanitarian law can play some role in the interpretation of human rights even if there are no more specific references in the respective treaty, and the European Court's recent decision in Hassan confirms this (more on this below).

Derogation clauses are relevant in this context to determine the exact relationship of human rights and international humanitarian law under a particular human rights treaty. Article 15 of the European Convention, for example, provides:

In time of war or other public emergency threatening the life of the nation any High Contracting Party may take measures derogating from its obligations under this Convention to the extent strictly required by the exigencies of the situation, provided that such measures are not inconsistent with its other obligations under international law.

The American Convention adopts a similar approach in article 27. Once such derogation clauses are in place, it typically becomes harder for the respective bodies to apply human rights and, through human rights, international humanitarian law. This is because the relevant treaty is then typically understood to settle the question as to what happens in times of armed conflict: If governments decide to derogate under such circumstances, courts are deprived of their jurisdiction. If, in turn, governments do not explicitly derogate and, therefore, choose to suspend human rights standards (in favour of the then applicable international humanitarian law), then, so the standard argument goes, they have to live with the consequences, in other words they have to apply human rights instead. This seems problematic, given that both conventions restrict the possibility to derogate to specific rights; most importantly, they do not allow states to derogate from the right to life where many of the conflicts between international humanitarian law and human rights arise in practice. ${ }^{21}$

20 See Isayeva $v$ Russia (n 2 above); also McCann $v$ United Kingdom (1995) 324 ECHR (ser A) 64; for the Inter-American system, see Las Palmeras $v$ Colombia, Preliminary Objections, IAm Comm of HR (4 February 2000) (ser C) No 67.

21 For a discussion of the conflicts between human rights and international humanitarian law typically arising here, see $M$ Sassòli \& LM Olson 'The relationship between international humanitarian and human rights law where it matters: Admissible killing and internment of fighters in non-international armed conflicts' (2008) 90 International Review of the Red Cross 599 n 871. 
Nevertheless, the derogation argument has been prominent, particularly in the jurisprudence of the European Court, until its recent decision in Hassan, which is worth a closer look. ${ }^{22}$

Addressing the legality of the capture of an Iraqi national, Tarek Hassan, by the British armed forces and his detention in Iraq during the hostilities in 2003, the European Court first pointed out that the right to liberty and security in article 5 of the European Convention did not square with the requirements for detention under the Third and Fourth Geneva Conventions, which had been invoked by the British government, even though it had not formally derogated from the Convention. Unlike in its previous jurisprudence, however, the European Court argued that the British government had explicitly asked the Court to disapply or modify Convention rights in favour of international humanitarian law. Drawing on article 31(3) of the Vienna Convention, the Court further reasoned that it was state practice not to derogate from human rights instruments during international armed conflicts and that it may, moreover, take other rules of international law, such as international humanitarian law, into account in interpreting the Convention. It proceeded to read article 5 of the European Convention in light of the Geneva Conventions, even though this ultimately entailed disapplying some of its procedural safeguards. In doing so, it did, however, interpret the Geneva requirements to provide for a 'competent body' to review the security detention of civilians (articles 43 and 78 GC IV), again in light of article 5 of the European Convention, requiring that such a body, while not a court, at least 'provide sufficient guarantees of impartiality and fair procedure to protect against arbitrariness'.

This more recent approach of the European Court aligns it more closely with the Inter-American Commission, ${ }^{23}$ and many legal scholars who have taken the position that the relationship between human rights and humanitarian law can only be decided with regard to the specific concrete case and context. ${ }^{24}$ In order to determine the more specific legal regime for the question at hand, a number of different factors are considered relevant, among them how much the situation resembles a classic battlefield scenario; how much effective control the government exercises over the area in question; previous declarations of intent; existing state practice; and so on. ${ }^{25}$ Although this approach leaves much to an assessment of the concrete situation

\section{Hassan (n 2 above).}

23 Abella (n 3 above).

24 Among many, see $\mathrm{N}$ Lubell 'Challenges in applying human rights law to armed conflict' (2005) 87 International Review of the Red Cross 737751 n 860; H Duffy 'Harmony or conflict? The interplay between human rights and humanitarian law in the fight against terrorism' in L van den Herik \& N Schrijver (eds) Counterterrorism strategies in a fragmented international legal order (2013) 482; Sassòli \& Olson (n 21 above); Hathaway et al (n 16 above).

25 C Droege 'Elective affinities? Human rights and humanitarian law' (2008) 90 International Review of the Red Cross 501 519; Sassòli \& Olson (n 21 above); Hathaway et al (n 16 above). 
at hand, certain questions, such as the treatment of captured combatants, typically are understood to be better covered by international humanitarian law, ${ }^{26}$ at least in the case of international armed conflicts.

The advantages and downsides of the different approaches have been explored elsewhere in the literature. ${ }^{27}$ However, here the question is a narrower one: How have the African Commission and the African Court so far approached this question and what approach to international humanitarian law fits best with the African system?

Before going into the details of existing case law, it is important to set out the basic textual parameters for the application of international humanitarian law under the African Charter. To begin with, unlike the European and American Conventions, the African Charter contains no explicit derogation clause for situations of emergency or war. This absence of a derogation clause suggests that Charter rights apply both in times of peace and armed conflict ${ }^{28}$ and this is a point frequently made by the African Commission, as will be seen. Importantly, articles 60 and 61 of the African Charter explicitly allow the African Commission to have regard to other sources of international law. Indeed, they instruct it to 'draw inspiration from international law on human and peoples' rights' (article 60) and to (article 61)

take into consideration, as subsidiary measures to determine the principles of law, other general or special international conventions, laying down rules expressly recognised by member states of the Organisation of African Unity, African practices consistent with international norms on human and peoples' rights, customs generally accepted as law, general principles of law recognised by African states as well as legal precedents and doctrine.

Since international humanitarian law does not, at least in the traditional sense, represent 'international law on human [...] rights', ${ }^{29}$ we must assume that article 61 rather than article 60 must guide the African Commission's approach to international humanitarian law, and this corresponds to its reasoning in the DRC case. ${ }^{30}$ Most African states are parties to the Geneva Conventions and Additional

26 Hathaway et al (n 16 above) 1917.

27 See Hathaway et al (n 16 above); M Milanović 'A norm conflict perspective on the relationship between international humanitarian law and human rights law' (2009) 14 Journal of Conflict and Security Law 459; O Ben-Naftali (ed) International humanitarian law and international human rights law (2011); and De Wet \& Kleffner (n 2 above); for up-to-date discussions of the normative questions arising under the different regional regimes, see jinks et al (n 3 above).

28 As Ouguergouz points out, this may not foreclose the possibility for derogations under the high standards of the Vienna Convention on the Law of Treaties, in particular arts 61 and 62 of the Convention; see F Ouguergouz The African Charter on Human and Peoples' Rights: A comprehensive agenda for human dignity and sustainable democracy in Africa (2003) 444; also AJ Ali 'Derogation from constitutional rights and its implication under the African Charter on Human and Peoples' Rights' (2013) 17 Law, Democracy and Development 7893.

29 Viljoen (n 4 above).

$30 \quad D R C$ (n 14 above) paras $70 \& 78$. 
Protocols, ${ }^{31}$ much of the content of which has in any case by now become part of customary international law. ${ }^{32}$

\subsection{African Commission on Human and Peoples' Rights}

A quasi-judicial institution with its seat in Banjul (The Gambia), the African Commission is - similarly to the comparable UN bodies and the Inter-American Commission - charged with a broad mandate for the protection of human rights. This includes examining state reports and promoting human rights in Africa more broadly. In the exercise of this function, the Commission has repeatedly called on state parties to observe the rules of humanitarian law. ${ }^{33}$ In its quasi-judicial function, the Commission addresses state and individual complaints about rights violations and has made a number of findings touching on the question of the relationship between human rights and humanitarian law that are of interest here.

In its early decisions, which were generally very short, the Commission did not at all or only in passing refer to international humanitarian law, in spite of the existence of armed conflicts. Typically, it merely insisted on the applicability of the African Charter even in times of 'war'. The first case in this regard represents the Commission's finding on grave and systemic human rights violations in Chad (Chad Mass Violations case) where it did not explicitly mention humanitarian law, but emphasised that ${ }^{34}$

[t]he African Charter, unlike other human rights instruments, does not allow for state parties to derogate from their treaty obligations during emergency situations. Thus, even a civil war in Chad cannot be used as an excuse by the state violating or permitting violations of rights in the African Charter.

The African Commission reaffirmed this position in a later finding on Sudan, ${ }^{35}$ at the time involved in a civil war, albeit in a less absolute key, emphasising that '[t]he restriction of human rights is not a solution to national difficulties: the legitimate exercise of human rights does not pose dangers to a democratic state governed by the rule of law ${ }^{\prime} .{ }^{36}$ For this reason, the Commission is sometimes taken to favour a

31 All African states are at least party to the Geneva Conventions and most states to the Additional Protocols I and II of 1977. See https://www.icrc.org/eng/assets/ files/annual-report/current/icrc-annual-report-map-conven-a3.pdf (accessed 30 July 2016).

32 J-M Henckaerts \& L Doswald-Beck (eds) Customary international humanitarian law (2009); see also the ICRC's online database, https://www.icrc.org/customary-ihl/ eng/docs/home (accessed 30 July 2016).

33 For an overview of the African Commission's attitude towards humanitarian law in its non-judicial function, see R Murray The African Commission on Human and Peoples' Rights and international law (2000) 129-145.

34 Commission Nationale des Droits de l'Homme et des Libertés v Chad (2000) AHRLR 66 (ACHPR 1995) para 21.

35 Amnesty International \& Others $v$ Sudan (2000) AHRLR 297 (ACHPR 1999).

36 Amnesty International (n 35 above) para 79. 
pro-human-based approach similar to that of the European Court. ${ }^{37}$ At the same time, the Commission also noted that '[e]ven if Sudan is going through a civil war, civilians in areas of strife are especially vulnerable and the state must take all possible measures to ensure that they are treated in accordance with international humanitarian law' ${ }^{38}$ Although not drawing directly on international humanitarian law, the Commission used international humanitarian law language in finding a violation of the right to life under the African Charter in the killing of 'unarmed civilians'. ${ }^{39}$ This is still broadly in line with the European Court's approach in its earlier decisions, ${ }^{40}$ and not particularly surprising for a human rights body charged mainly with the application of human rights. It is also important to note that both the Chad and the Sudan cases dealt with situations of civil war and, hence, non-international rather than international armed conflicts, where humanitarian law is least worked out as a matter of law and its relationship with human rights has long been unclear.

However, things changed in the African Commission's later jurisprudence. For the first and, to date, only time, the Commission explicitly addressed humanitarian law in some detail in its decision on the DRC conflict. ${ }^{41}$ The case had been brought by the DRC against Burundi, Rwanda and Uganda, seeking redress against the violations of both human and peoples' rights committed by the enemies' armies on the territory of the DRC. The Commission's treatment of international humanitarian law here is both detailed and unclear and thus requires closer examination.

Already in the admissibility phase, the Commission draws on articles 60, 61 and 23 to argue that the activities of the armed forces of the respondent state parties are matters of humanitarian law and hence 'fall within the mandate of the [African] Commission' ${ }^{42}$ It is not clear exactly what this phrasing implies. Viljoen has argued that it suggests a separation of humanitarian law from the Court's actual mandate (human rights), again affirming that the latter are applicable in cases of armed conflict, ${ }^{43}$ but it may also denote that the Commission implicitly assumes a mandate for humanitarian law based on articles 60 and 61, invoked immediately afterwards. It hence leaves open the question of which of the two common approaches of human rights bodies to humanitarian law the African Commission is going to follow: whether it will merely interpret African Charter rights during armed conflicts in light of humanitarian law standards, or

37 See DL Tehindrazanarivelo 'The African Union and international humanitarian law' in R Kolb \& G Gaggioli (eds) Research handbook on human rights and humanitarian law (2013) 503.

38 Amnesty International (n 35 above) para 50.

39 Amnesty International para 48.

40 See eg Ergi v Turkey (1998) ECHR 23818/94 para 79.

41 DRC (n 14 above).

42 DRC para 64.

43 Viljoen (n 4 above) 308. 
whether it will directly apply humanitarian law through articles 60 and 61.

In the following discussion on the merits, the African Commission continues oscillating between these two approaches. In doing so, it closely mirrors the Inter-American Court's approach in the BámacaVelazquez decision, where the Inter-American Court similarly argued that it would take the Geneva Conventions into consideration in interpreting the American Convention, ${ }^{44}$ but at the same time suggested that the Court could find that violations of the Convention also violated international humanitarian law. ${ }^{45}$ Invoking the text of articles 60 and 61, the Commission initially sets out to follow an interpretive approach, qualifying the Geneva Conventions as general principles of international law falling under article 61 of the African Charter. ${ }^{46}$ It proceeds to declare the massacres, rapes, mutilations, mass transfers of populations and looting of peoples' possessions committed in the DRC as 'inconsistent' with the Fourth Geneva Convention and Additional Protocol I and subsequently 'also' as violations of the African Charter right against discrimination and right to life. It is, therefore, not entirely clear whether these acts constitute Charter violations merely on the basis of article 61 or more broadly of certain Charter rights read in light of the instructions of article 61.

The subsequent arguments on the merits then shift back and forth between a more independent international humanitarian law analysis on the basis of article 61 and an interpretive approach that reads African Charter rights in light of international humanitarian law. The African Commission engages in comparative detail with individual provisions in the Geneva Conventions, finding multiple violations of humanitarian law, which are classified as African Charter violations merely on the basis of articles 60 and $61: 47$

The raping of women and girls, as alleged and not refuted by the respondent states, is prohibited under article 76 of the First Protocol Additional to the Geneva Conventions of 1949, which provides that 'women shall be the object of special respect and shall be protected in particular against rape, forced prostitution and any form of indecent assault. It also offends both the African Charter and the Convention on the Elimination of All Forms of Discrimination against Women; and on the basis of articles 60 and 61 of the African Charter find the respondent states in violation of the Charter.

This suggests that rather than reading African Charter rights merely in light of international humanitarian law, the African Commission treats international humanitarian law essentially as a part of the Charter, incorporated by article 61. This impression is reinforced in the following analysis, where the Commission again analyses the same acts, but this time in light of both international humanitarian law and

44 Bámaca Velásquez (n 3 above) para 209.

45 Bámaca Velásquez para 208.

$46 \quad D R C$ (n 14 above) paras $70 \& 78$.

$47 \quad D R C$ para 79. 
African Charter rights. In this vein, for example, it qualifies the mass burial of victims of the conflicts as a violation both of the right to cultural development in article 22 of the African Charter and additionally as prohibited under article 34 of the Additional Protocol I and, hence, as a violation of the African Charter on the basis of articles 60 and 61.48

Other passages in contrast are again more ambiguous, leaning perhaps towards a more interpretive approach, such as the analysis of the besieging of a hydroelectric dam, where the African Commission seems to use international humanitarian law to give content to a provision of the African Charter, namely, article 23. However, even here its formulation is vague at best: ${ }^{49}$

As noted previously, taking article 56 [of the Additional Protocol I to the Geneva Conventions] quoted above into account and by virtue of articles 60 and 61 of the African Charter, the [African] Commission concludes that in besieging the hydroelectric dam in Lower Congo province, the respondent states have violated the [African] Charter ... By parity of reason, and bearing in mind articles 60 and 61 of the [African] Charter, the respondent states are in violation of the said Charter with regard to the just noted article 23 [of the African Charter].

Some paragraphs later, the destruction of the dam is additionally and, rather in passing, also qualified as a violation of the Charter's right to property. ${ }^{50}$

Given this, it is doubtful whether it is correct to conclude that 'the African Commission has found only violations of human rights law, but in so doing, has sought interpretive guidance from international humanitarian law', 51 even though - as will be argued below - this conclusion represents a better, that is, legally more plausible reading of the African Charter. However, if the Commission really were taking only international humanitarian law into account in interpreting human rights, one would expect to see a different kind of legal analysis that starts out with the human rights provision in question and then draws on international humanitarian law to give content to this provision, in discussing its scope or limitations. One would, for example, expect to see the Commission analyse whether the destruction of the dam violates the right to property or, for that matter, the right to national and international peace and security. The first question in this regard would presumably be whether the dam constituted public or private property and if the first, whether public property enjoys protection under the African Charter. In this latter regard, the African Commission might then have drawn on article 23 of the Hague Convention with its qualified protection of the 'enemy's property' to argue for a broad reading that includes public property.

$48 \quad$ DRC para 87.

49 DRC paras 84-85.

$50 \quad D R C$ para 88.

51 Viljoen ( $\mathrm{n} 4$ above) 314. 
In the next step, one would expect the Commission to engage with the question whether the right to property could have been limited as a matter of general interest to the community. Again, the Commission might now have taken the limitations of the Hague Conventions for cases of military necessity into account. Alternatively, if the Commission wanted to base its argument on article 23, one would expect some more detailed analysis of what peace and security implies, drawing only in the second step on international humanitarian law. But none of this really matches the Commission's approach. Instead, the international humanitarian law analysis of particular acts more often than not stands by itself. There is either no explanation of how and why the Commission incorporates international humanitarian law within a particular African Charter right where one would have expected a much more detailed legal analysis of the Charter right in question, or the Commission straightforwardly qualifies violations of international humanitarian law as Charter violations under articles 60 and 61 . The destruction of the hydroelectric dam, for example, is qualified three times as an African Charter violation: once on the basis of articles 60 and 61 alone (drawing on article 56 AP I of the Geneva Conventions) and not on the basis of other substantive Charter rights, and twice in terms of particular (substantive) Charter rights, of article 23 as interpreted in light of international humanitarian law and of article 14 on its own.

The direction changes again in a later decision on the Darfur conflict, where the African Commission once again takes a more interpretive approach. ${ }^{52}$ Dealing with abuses of the civilian population in Darfur, it falls back on its initial position of avoiding any explicit reference to humanitarian law, merely drawing on international humanitarian law language: Recognising that an 'armed conflict'53 has taken place in Darfur, it incorporates in its reasoning explicit references to the humanitarian law principle of distinction, pointing out that ' $[\mathrm{t}]$ he respondent state, while fighting the armed conflict, targeted the civilian population, instead of the combatants. This in a way was a form of collective punishment, which is prohibited by international law.'

The differences between these decisions demand explanation. The most likely reply may be that Commission members either did not engage sufficiently with this question at all, or perhaps that their composition had changed between the two cases and that the new members simply took a different position on the issue. However, given the ambiguous approach to international humanitarian law even within individual decisions themselves, it seems more likely that the Commission has simply not yet developed a firm stance on the role of international humanitarian law in its jurisprudence. One should,

52 Sudanese Human Rights Organisation \& Another $v$ Sudan (2009) AHRLR 153 (ACHPR 2009) (Darfur case).

53 Darfur case (n 52 above) para 201. 
therefore, be wary of treating either the $D R C$ or the Darfur decision as firmly established judicial doctrine.

\subsection{African Court on Human and Peoples' Rights}

The African Court came into operation in 2006. Since then, it has only decided a handful of cases, which partly reflects the fact that some states have not yet ratified the African Court Protocol and even fewer have accepted that individuals may directly access the Court. ${ }^{54}$ There are now plans to merge the African Court with the African Court of Justice, which will have jurisdiction over criminal justice issues as well. ${ }^{55}$ It remains to be seen whether the new institution will become more relevant.

So far, only one decision of the African Court, a referral from the African Commission, addresses a situation of armed conflict, namely, its decision on provisional measures against Libya. ${ }^{56}$ Although the decision makes mention of the fact that the African Peace and Security Council condemned the use of force in Libya 'in violation of human rights and international humanitarian $\mathrm{law}^{\prime}, 57$ the Court does not itself draw on international humanitarian law. This may be due in part to the fact that the decision only deals with provisional measures and follows a minimalist French style of legal reasoning. It does, however, call on Libya to end actions contrary to both the African Charter and 'other international human rights instruments to which it is party'. Of course, this raises the question whether the Geneva Conventions and additional protocols may be considered as 'other international human rights instruments' in this context, on which the Court is explicitly allowed to draw under article 3 of its Protocol. The African Commission's assessment in the DRC decision suggests that the Geneva Conventions do not qualify as human rights treaties, but instead are other international treaties or at least general principles of international law. On the other hand, one may argue for a more generous reading focusing on the purpose of the relevant treaty or at least particular clauses and, therefore, qualify at least some parts of

54 For a table of ratifications, see http://www.achpr.org/instruments/courtestablishment/; see also F Viljoen 'From a cat into a lion? An overview of the progress and challenges of the African human rights system at the African Commission's 25 year mark' (2013) 17 Law, Democracy and Development 298307 309.

55 See Protocol on the State of the African Court of Justice and Human Rights, http:// www.interights.org/userfiles/Documents/MergedCourtProtocol.pdf (accessed 30 July 2016). For an early assessment, see M Otieno 'The Merged African Court of Justice and Human Rights (ACJ\&HR) as a better criminal justice system than the ICC: Are we finding African solutions to African problems or creating African problems without solutions?' 3 June 2014, published in SSRN http://ssrn.com/abstract $=2445344$ (accessed 30 July 2016).

56 African Commission on Human Rights $v$ Great Socialist People's Libyan Arab Jamarihiya (2011) App 004/11.

57 Libyan Arab Jamarihiya (n 56 above) para 21. 
humanitarian law as a 'human rights instrument', as Viljoen suggests. ${ }^{58}$ In either case, the Court can at least rely on articles 60 and 61 of the African Charter and thus draw on other sources of international law if it does not directly apply them in its jurisprudence.

\section{Recommendations}

The current approaches to humanitarian law of both the African Commission and Court leave room for improvement. First of all, the Commission should develop a more coherent and consistent approach to international humanitarian law. While other international bodies also struggle with this task, a more consistent approach would be especially useful in the African context and in light of the Commission's collaborative role with the Peace and Security Council of the AU (PSC), which has recently taken on a broad peace-keeping mandate. ${ }^{59}$ Since the PSC has so far not developed a consistent doctrine of its own with regard to the relationship between international humanitarian law and human rights in peacekeeping missions, ${ }^{60}$ the African Commission is institutionally well-suited to provide guidance in this regard. The same may be true for the African Court, particularly if its merger with the African Court of Justice proceeds, which seems to be unclear at the moment as states seem reluctant to proceed with ratification. ${ }^{61}$

The next question must be what approach to international humanitarian law is most appropriate under the African Charter. Insofar as current decisions either ignore international humanitarian law entirely or apply it more or less directly through article 61, they are hard to square with the text of the Charter. Ignoring international humanitarian law disregards the clear instruction in article 61 ('shall') to take international law, such as humanitarian law, into consideration. This also presents an important counter-argument to those who are skeptical of any application of international humanitarian law by human rights bodies for reciprocity reasons,

58 Viljoen (n 4 above).

59 Arts 6(d) and 7 of the Protocol Relating to the Peace and Security Council (PSC) of the African Union for the Peace and Security Council's mandate, and art 19 of the Protocol for its relationship with the African Commission on Human and Peoples' Rights.

60 J Fowkes 'The relationship between international humanitarian law and IHRL in peacekeeping operations: Articulating the emerging AU position' (unpublished manuscript, on file with author).

61 See http://www.theeastafrican.co.ke/news/Mixed-reactions-to-Kenya-s-push-toestablish-African-court/-/2558/2616388/-/12dkljgz/-/index.html. However, there have been recent attempts by the $A U$ to expedite the ratification process. See eg http://trendingnewsroom.com/readfeed/1361/african-states-move-to-create-acourt-to-replace-icc (accessed 30 July 2016). 
given that such bodies can only hold states, but not non-state actors, accountable. ${ }^{62}$ However, the rather free-wheeling, direct application of international humanitarian law observed in parts of the $D R C$ decision is similarly problematic with regard to the text of the African Charter. To take international law into consideration 'as subsidiary measures to determine the principles of law' (article 61) implies that an interpretive process is already ongoing. According to article 61, humanitarian law can, therefore, play only a subsidiary role; it can help to fill gaps and give content to what are otherwise often vague Charter provisions and thus assist with their application in concrete cases. ${ }^{63}$ Article 61 mirrors the similarly-phrased article 31(3)(c) of the Vienna Convention. Although the exact meaning and scope of article $31(3)$ (c) are contested, it is not usually understood to provide a means to apply other treaties directly or indeed to replace provisions of one treaty by the rules and principles of another treaty. ${ }^{64}$

Yet, text and doctrine are not everything in legal interpretation. The interpretive approach suggested by the language of the African Charter has in the European system created problems when the two bodies of law conflict, with the European Court not infrequently applying human rights in the context of armed conflict where international humanitarian law may be more appropriate. In doing so, it risks overstretching the limits of what states can and are in practice willing to do in a situation of armed conflict. Some commentators have, therefore, called on the European Court to apply the lex specialis rule in favour of international humanitarian law during armed conflicts, even if this may mean that the Court cannot exercise its jurisdiction in every case. ${ }^{65}$ The recent Hassan decision has now found a way around this dilemma with its reliance on the government's explicit pleading to modify or disapply Convention rights in light of

62 R Provost 'Reciprocity in human rights and humanitarian law' (1994) 65 British Yearbook of International Law 383. However, it is important to keep in mind that, according to established precedent, the African Charter applies both in times of peace and armed conflict. The reciprocity argument in this context would mainly serve to increase (one-sided) obligations for state parties who are bound by the (usually) higher standards of Charter rights as opposed to international humanitarian law.

63 See also SS Yeshanew 'Treaty interpretation in the African regional human rights system: Streamlining the "conventional" and the "special"' (2014) 20 East African Journal of Peace and Human Rights 1-17.

64 See eg C McLachlan 'The principle of systemic integration and article 31((3)(c) of the Vienna Convention' (2005) 54 International and Comparative Law Quarterly 279; RK Gardiner Treaty interpretation (2015) 289; for an overview over the recent debate, see also the report on the ASIL panel 'Everybody come together over me: Systematic integration and Vienna Convention art 31(3)(c)' by I Khan, ASIL cable, 16 April 2014, https://www.asil.org/blogs/everybody-come-together-over-mesystematic-integration-and-vienna-convention-art-313c (accessed 30 July 2016). The Hassan decision of the European Court is not a counter-argument in this context, as the Court explicitly emphasised the government's own pleading as a condition for dis-applying or modifying the Convention in favour of international humanitarian law (Hassan (n 2 above)).

65 Oellers-Frahm (n 2 above) 361; also R Provost International human rights and humanitarian law (2005) 349-350. 
international humanitarian law, but it remains to be seen how the Court will deal with situations where such explicit pleading is absent. 66

In light of these experiences, it is worth enquiring whether the African Commission's more direct application of international humanitarian law in the $D R C$ case may not in the long run be better suited as a realistic and international humanitarian law-friendly approach. Such an approach may allow the Commission to recognise conflicts between the two bodies of law where they arise, rather than muddling through them only ultimately to favour African Charter rights, which may not fit the particular situation at hand. This indeed is a risk of the interpretive approach: By staying within the human rights framework, humanitarian law can only be taken into consideration as long as it does not clearly conflict with the language of Charter rights. If it does, Charter rights must necessarily prevail, and it is then that human rights bodies risk adopting unrealistic perspectives on what states are allowed during armed conflict. A direct application of international humanitarian law, in contrast, is less prone to subordinating international humanitarian law to human rights in cases of conflict, but it comes with other risks.

A direct application of international humanitarian law is not only problematic with regard to the text of the African Charter and the African Commission's mandate, but its benefits are also perhaps more questionable in the African than in the European context. Many of the problems under the European Convention have arisen because the European Convention sets out both narrow and detailed textual provisions that make an interpretation of Convention rights in light of international humanitarian law more difficult than elsewhere. In particular, the right to life in article 2 and the right to liberty and security in article 5 of the European Convention are framed in very detailed terms that make it difficult to accommodate more lenient international humanitarian law standards with regard to the killing or detention of combatants, as the jurisprudence of the European Court demonstrates.

In contrast, the African Charter sets out individual Charter rights in comparatively less detail and, in doing so, leaves considerable room to take humanitarian law standards into account, as is evident in the traditional fields where problems arise, namely, the rights to life and liberty. The African Charter merely protects the right to life against arbitrary deprivations and the right to liberty against any deprivation of freedom 'except for reasons and conditions previously laid down by law', similarly ruling out 'arbitrary' arrest or detention. ${ }^{67}$ In determining what counts as an arbitrary deprivation of life or liberty,

66 The long-awaited judgment of the European Court in Georgia $v$ Russia (II), App 38263/08 is supposed to shed light on this question.

67 See art 4 (right to life) and art 6 (right to liberty) of the African Charter on Human and Peoples' Rights. 
the African Commission is, therefore, free to take the Geneva Conventions and Additional Protocols as well as customary international humanitarian law into account. In doing so, it can rely on the ICJ precedent in the Nuclear Weapons case: ${ }^{68}$

The test of what is an arbitrary deprivation of life, however, then falls to be determined by the applicable lex specialis, namely, the law applicable in armed conflict, which is designed to regulate the conduct of hostilities.

A potential hurdle to reading international humanitarian law into African Charter rights may, however, be article 7 of the Charter which entails a general right to have one's cause heard, comprising 'the right to an appeal to competent national organs against acts of violating his fundamental rights as recognised and guaranteed by conventions, laws, regulations and customs in force' and article 4, 'the right to be tried within a reasonable time by an impartial court or tribunal'. It, therefore, envisages a more classical law enforcement model and has been read by the Commission more broadly as a right to fair trial, ${ }^{69}$ limiting, among others, the jurisdiction of military tribunals to 'offences of a pure military nature committed by military personnel'. ${ }^{70}$ How, then, does this square with articles 5 and 21 of the Third Geneva Convention, which allow for the detention of prisoners of war until the end of hostilities, granting only a right to a status determination by a 'competent tribunal', and of civilians for security reasons under articles 78 and 43 of the Fourth Geneva Convention, which is subject only to periodical review and appeal by an 'appropriate court or administrative body'?

The answer is that it does. For once, it seems already doubtful whether article $7(1)(a)$ is applicable to international armed conflicts, given that its wording ('competent national bodies') is clearly tailored to domestic rights violations. Even if we assume that it applies, the wording ('bodies') does in itself not necessarily require more than a status review board for prisoners of war or an 'administrative body' with regard to the security detention of civilians. Insofar as the Commission has understood article 7 more broadly as the right to a fair trial, limiting, inter alia, the jurisdiction of military commissions which will typically be involved in status reviews for prisoners of war and security detention for civilians, it is important to emphasise that it has done so in the context of criminal convictions. It is, therefore, not in conflict with the Geneva Conventions as long as such bodies are not pronouncing criminal sentences. Of course, this does not mean that military review boards should not be structured and staffed in such a way as to guarantee sufficient fairness and impartiality. Indeed,

68 Nuclear Weapons (n 18 above).

69 C Heyns 'Civil and political rights in the African Charter' in MD Evans \& R Murray (eds) The African Charter on Human and Peoples' Rights: The system in practice, 1986-2000 (2002) 155-163.

70 Dakar Declaration on the Right to a Fair Trial in Africa, adopted through Res 41 (XXVI) 99 Resolution on the Right to Fair Trial and Legal Aid in Africa, 15 November 1999, and recommendations. 
they must, as the International Committee of the Red Cross (ICRC) commentary on article 43 GC IV confirms. ${ }^{71}$ Last but not least, the more specific standards required by the Geneva Conventions, such as periodic review, can be accommodated in the interpretation of article 7.

The situation in non-international armed conflicts is different insofar as there is no explicit legal basis for detention in Additional Protocol II, though it is contested whether the rules for international armed conflicts may by analogy apply here. ${ }^{72}$ In either case, conflicts with article 7 of the African Charter are unlikely to arise. As has been seen, article 7 leaves room for an (analogous) application of the Geneva rules on detention. In all other cases domestic law must conform to article 7 standards. If one selects the humanitarian law route, however, it seems appropriate in non-international armed conflicts to adopt a human rights-friendly reading of the relevant norms and add, along the lines of the European Court's recent Hassan decision, that there must also be 'sufficient guarantees of [...] fair procedure to protect against arbitrariness'. 73

Finally, like any human rights instrument, the African Charter allows for limitations of rights. Of the three rights discussed here, only the right to liberty contains an explicit limitation requirement, namely, that deprivations of liberty must be in accordance with the conditions previously laid down by law. This broad formulation may suggest that states have wide leverage to curtail the right to liberty, but the African Commission has refused to adopt a broad understanding of this clause as a general 'claw-back' clause. Instead, it has read this formulation more narrowly, requiring in particular that international rather than domestic legal standards must be satisfied, referring to articles 60 and 61 of the Charter. Commentators have taken this as a broader reference to international practice, requiring in addition that domestic limitations meet proportionality standards in being necessary and proportionate to the interest protected. ${ }^{74}$

This ultimately points in the same direction as article 27 of the African Charter, for even though the Charter does not contain an explicit general limitation clause, the African Commission has de facto turned article 27 into such a clause. Providing that rights 'shall be exercised with due regard to the rights of others, collective security, morality and common interest', the Commission has read article 27 to

71 ICRC commentary to art 43 of the Geneva Convention IV, https://www.icrc.org/ applic/ihl/ihl.nsf/Comment.xsp?viewComments=LookUpCOMART\&articleUNID= A0FD86E2FBA558E0C12563CD0051BD2C (accessed 30 July 2016).

72 See the recent debate on the decision of the British High Court in Serdar Mohammed v Ministry of Defence [2014] QB EWHC 1369; on the EJIL blog, eg by M Milanovic 'High Court rules that the UK lacks international humanitarian law detention authority in Afghanistan' http://www.ejiltalk.org/high-court-rules-thatthe-uk-lacks-ihl-detention-authority-in-afghanistan/ (accessed 30 July 2016). See also Al Jedda (n 9 above).

73 Hassan (n 2 above) para 106.

74 Heyns (n 69 above). 
stipulate a broader proportionality requirement. ${ }^{75}$ In doing so, it has followed the international human rights trend with its approach to proportionality, requiring that limitations be both 'absolutely necessary for the advantages which are to be obtained' and 'strictly proportionate' with them. ${ }^{76}$ In addition, the Commission has read article 27(2) of the African Charter to stipulate a sort of essential core guarantee in requiring that the right in question may not become 'illusory'. 77

For advocates of international humanitarian law, this is good news: Proportionality offers an assessment of rights limitations that is tied to the aim and purpose of the limitation and is, therefore, broadly suited to deal with situations of both armed conflict and peace. This is not to say that proportionality implies that anything goes - the robust jurisprudence of many constitutional courts employing proportionality shows that this would be in error ${ }^{78}$ - but merely that grave circumstances, such as armed conflict, may justify rights infringements that go beyond what is acceptable in times of peace.

Of course, proportionality in a human rights context differs from a proportionality analysis as it is conducted in humanitarian law. This is because international humanitarian law proportionality restricts the goods to be weighed - military advantage versus the (collateral) damage to civilians (article 51(5)(b) of Additional Protocol I) whereas human rights proportionality has a broader scope which grants protection not only to civilians but also to soldiers, and is in principle open towards considering not only the rights at stake in particular military actions, but also the causes of armed conflict and the broader values involved. Indeed, proportionality is open to a large range of considerations, and this may for some serve as a welcome argument to break down the currently-existing strict boundaries between ius ad bellum and ius in bello. ${ }^{79}$ However, if proportionality in a human rights analysis is broader than under international humanitarian law, this is not to say that under sufficiently war-like circumstances, it cannot be read in the narrower sense of international humanitarian law. After all, not all considerations must be accorded the same weight in the balancing test of proportionality. Therefore,

75 Media Rights Agenda \& Others v Nigeria (2000) AHRLR 200 (ACHPR 1998); see also Viljoen (n 4 above) and Heyns (n 69 above).

76 Media Rights Agenda (n 75 above) para 69.

77 Media Rights Agenda para 70. The African Court has broadly followed the African Commission in this approach; see Tanganyika Law Society \& Another App 9/2011 para 106.1; Mtikila v Tanzania African Court on Human and Peoples' Rights App 11/2011 para 107.2.

78 A Stone Sweet \& J Mathews 'Proportionality balancing and global constitutionalism' (2008) 47 Columbia Journal of Transnational Law 72; more broadly A Barak Proportionality: Constitutional rights and their limitations (2012).

79 Eg CJ Dunlap 'The end of innocence: Rethinking non-combatancy in the postKosovo era' (2000) 14 Strategic Review 9; for a critique, S Oeter 'Comment: Is the principle of distinction outdated?' in $\mathrm{H}$ von Heinegg et al (eds) International humanitarian law facing new challenges (2007) 53. 
one does not necessarily need to go as far as the Israel Supreme Court, which frequently blurs its international humanitarian law and human rights analysis, emphasising that proportionality is both a constitutional principle and a general principle of international law. ${ }^{80}$ For even if human rights proportionality differs from international humanitarian law proportionality by increasing the scope of what needs to be taken into account, its results must not necessarily differ from international humanitarian law: While even an enemy soldier's life must be attributed a value under human rights proportionality, it may routinely be outweighed by military advantages in case of an armed conflict. (This may change when child soldiers, whether forcibly recruited or not, are involved, since their right to life will weigh more heavily given their lack of autonomy at the time of their recruitment, but their life, too, may not always outweigh military necessity.) ${ }^{81}$ Certainly, the African Commission's additional requirement that a right may not become illusory raises further questions in this regard: Does a soldier's right to life not become illusory if it is routinely subjected to other considerations in an armed conflict? No doubt, good arguments may be found for either side here, yet, if we seek to impose realistic constraints on warfare, much suggests that the answer will, at least in the standard cases, not be a resounding 'yes'.

Particularly during international armed conflict, international humanitarian law can give content to vague human rights provisions, something much needed in this context. Whereas international human rights bodies and courts have by now developed considerable jurisprudence on many human rights issues, the same is not true for the application of human rights in emergency scenarios or during armed conflict. Indeed, the recent discussion on human rights in the 'war on terror' with its very disparate voices from all ends of the political spectrum emphasises that we are still some way from agreeing on what emergencies and terror should mean for human rights protection. In international armed conflicts, however, there is an established body of humanitarian law. Even human rights bodies confronted with such situations would, therefore, do well to draw on the Geneva Conventions and Additional Protocols.

This is somewhat, but not entirely, different for non-international armed conflicts, which are more prevalent in Africa and governed only

80 Beit Sourik Village Council $v$ The Government of Israel Israel Supreme Court, 29 February 2004, HCJ 2056/04 para 38. For a positive assessment of the Israel Supreme Court's approach, see G Nolte 'Thin or thick? The principle of proportionality and international humanitarian law' (2010) 4 Law and Ethics of Human Rights 245.

81 There is surprisingly little literature on this question so far, most of which is concerned with the ethics rather than the law of killing child soldiers in self defence; see eg ME Vaha 'Child soldiers and killing in self-defence: Challenging the "moral view" on killing in war' (2011) 10 Journal of Military Ethics 36; from a military practice perspective, see C Borchini et al 'Child soldiers: Implications for US forces' Marine Corps Warfighting Lab Quantico VA CETO-005-02 2002. 
by Common Article 3, the Additional Protocol II to the Geneva Conventions as well as a body of customary law, the status of which is, however, often contested. Because explicit written rules are much rarer here, human rights already play an important role in this field. In determining the state of customary law in this area, the ICRC, for example, routinely draws on human rights standards as well as the rules for international armed conflicts and soft law. ${ }^{82}$ However, the fact that the law is less clear regarding non-international armed conflict should not be a reason to adopt a pure human rights approach in the case of non-international armed conflict. It is granted that a more context-sensitive analysis will be necessary here than in the case of international armed conflict. Nevertheless, while any application of customary law is fraught with difficulties, there is considerable useful scholarship as well as extensive work by the ICRC in this area. Together with Common Article 3 and Additional Protocol II, this body of work can provide important guidance to courts dealing with situations of armed conflict, often lacking under a human rights paradigm. Finally, if the law here is nevertheless less determinate than international humanitarian law regarding international armed conflict, this to some degree appropriately reflects that many contemporary conflicts no longer represent classical battlefield situations. That human rights standards will have to be modified to some extent to meet demands for security is nothing unusual, and proportionality is in many ways ideally suited to accommodate shifting levels of threat and violence: Many domestic constitutional courts have in the past reduced their human rights standards in dealing with terrorism. Internal armed conflicts, therefore, present merely the next level downwards on the ladder of rights protection.

As a result, the most important objection to an interpretive approach in other systems such as the European - namely, that it does not leave sufficient room to adopt international humanitarian law standards in situations of armed conflict - is not persuasive in the African context. More openly-formulated textual provisions together with a broad understanding of proportionality, as developed by the African Commission, enable African institutions to take an international humanitarian law-friendly approach to their interpretation of African Charter rights without the risk of overstretching member states' obligations in armed conflicts.

Of course, the debate does not end here. An interpretive approach will further melt the boundaries of human rights and humanitarian

82 See ICRC (n 32 above). Eg, in defining what constitutes a 'fair trial' with all the necessary institutional and other guarantees, the ICRC report refers to multiple human rights instruments (354 ff.); more specifically, it explains that an 'independent and impartial tribunal' must be independent from other branches and in particular the executive, drawing on decisions by the UN Human Rights Committee, the African Commission on Human and Peoples' Rights, the European Court of Human Rights and the Inter-American Commission on Human Rights, n 353. 
law. Human rights advocates have in the past feared that this will in the long run damage and reduce human right protection. ${ }^{83}$ Rights will, in other words, no longer be the trumps we want them to be. This squares with the frequent critique of tools such as proportionality, which can - so some critics worry - justify just about anything if the dangers on the other side are sufficiently great. ${ }^{84}$ Yet, this development is neither as problematic as it may seem at first glance, nor is it unavoidable. It is not as problematic as it may seem because there are - at least as a matter of law - reasonably clear thresholds for when an international or non-international armed conflict exists and when, therefore, humanitarian law becomes applicable. ${ }^{85}$ Second, and more importantly, proportionality does not force us to go all the way down the sliding scale; it allows us to choose a more structured approach to questions of rights limitation. The history of proportionality demonstrates that there is room for this possibility, as proportionality initially evolved from a more structured, three-tiered test in German constitutional jurisprudence that set different requirements for each particular kind or level of rights limitation. ${ }^{86}$ In those cases where an international armed conflict exists, proportionality may, therefore, be understood to generally afford the level of rights protection guaranteed by the applicable humanitarian law. In non-international armed conflicts, in turn, there is a different, if less definite, set of rules. A more context-specific approach will be necessary here.

Given this need for context-sensitivity and nuanced legal reasoning, of course, it may be of concern that the jurisprudence of the African Commission and, indeed, the African Court has frequently been of questionable quality. The Commission's analysis has in the past often been extremely thin and superficial. Rather than engaging in a detailed legal analysis, it tends to jump from the statement of facts immediately to the legal conclusion that a specific provision in the African Charter has been violated without providing much explanation or reasoning. For the kind of context-sensitive approach that will be necessary to address particularly non-international armed conflicts adequately, a more detailed and considered legal analysis is vital. Without this, there is not only the risk of damaging the

83 C Byron 'Blurring of the boundaries: The application of international humanitarian law by human rights bodies' (2006) 47 Virginia Journal of International Law 839.

84 For a convincing discussion of some of these objections, see Stone Sweet \& Mathews (n 78 above).

85 See Prosecutor $v$ Dusko Tadic $a / k / a$ 'Dule', Decision on the Defence Motion for Interlocutory Appeal on Jurisdiction, 2 October 1995 (ICTY Appeals Chamber) paras $66 \mathrm{ff}$. For a more detailed theoretical discussion, see JK Kleffner 'Scope of application of international humanitarian law' in D Fleck (ed) The handbook of international humanitarian law (2013) paras 201-209.

86 Pharmacies, BVerfGE 7, 377; see also for the development of German proportionality D Grimm 'Proportionality in Canadian and German constitutional jurisprudence' (2007) 57 University of Toronto Law Journal 383 and J Bomhoff Balancing constitutional rights: The origins and meanings of post-war legal discourse (2013). 
Commission's authority by overstretching human rights obligations in situations of civil war, but also of lowering human rights protection in the long run if it is not sufficiently clear what the respective requirements and thresholds are in different circumstances.

The African Commission's minimalist approach may partly be a reflection of French legal traditions present in much of Francophone Africa. It is, therefore, important for African lawyers to recall the key role that preparatory materials and the Advocate-General's advisory opinion play in the French system in explaining minimalist French judicial decisions, ${ }^{87}$ but which are lacking in the African system. Moreover, there is typically less of an established legal culture in regional human rights courts ${ }^{88}$ and little supporting doctrine in whose terms observers may be able to understand the reasoning behind scarce judicial decisions. More than in the case of other courts, it is important for regional bodies such as the African Commission to make the details of their reasoning transparent to the parties as a means of strengthening their authority.

One should also not defend the often vague and unclear language of the African Commission as an adequate reaction to the kind of situations the Commission is often confronted with. Only at first glance may we think that when citizens are killed in their thousands, tortured or detained without any possibility of appeal, there is no need for a detailed legal analysis because things are clear. Given the increase in non-traditional conflicts and the blurring between classical wars and internal riots, they will not always be so. Much therefore suggests that the African Commission should take a more structured and better reasoned approach in its current decision-making practice, even in cases that do not seem to call for a more legalistic approach on their own. As a matter of legal style, the Anglo-American tradition is better suited here to reconcile the strong emotional and rhetorical language appropriate to make a moral point with detailed legal analysis.

87 M de S.-O.-I'E Lasser Judicial deliberations: A comparative analysis of transparency and legitimacy (2004).

88 That is not to say that regional and international courts will not be able to establish their own legal and institutional culture. Nevertheless, such internal 'cultures' will generally be thinner than long-standing national legal traditions. A skeptical analysis of the European Court's decision making in terms of the common or civil law pedigree of its judges (showing no differences in decision making along these lines), however, relies on an outdated and stereotyped idea of common law versus civil law and should, therefore, be taken with a pinch of salt. $E$ Voeten 'The impartiality of international judges: Evidence from the European Court of Human Rights' (2008) 102 American Political Science Review (2008) $419 \mathrm{ff}$. For a broader discussion of the role of personality and legal culture in shaping international adjudication, see D Terris et al 'The international judge: An introduction to the men and women who decide the world's cases' (2007). 


\section{Conclusion}

Keeping these things in mind, there are no reasons why the African Commission and Court should not be successful in elaborating a strong interpretive approach to the relationship between human rights and international humanitarian law in situations of armed conflict. By infusing the broad provisions of the African Charter with the standards of international humanitarian law, many of the inconsistencies and problems of the European approach in treating armed conflicts like situations of normalcy and peace can be avoided, without having to dismiss cases where no other institutions may be available to provide a measure of justice to the victims.

From a strategic perspective, too, this approach seems preferable to a stronger human rights-focused model. The African Commission correctly emphasises that regional African institutions must curb excesses of state power, but they also need to make sure that they do not reach too far into what many countries and executives consider classical state prerogatives. The downfall of the Southern African Development Community (SADC) tribunal $^{89}$ demonstrates the dangers associated with a lack of circumspection in African regional courts, which the African Commission and Court have so far done well to avoid. Drawing on humanitarian law may thus allow them to balance their human rights expectations adequately with states' concern for domestic security in a way that is likely to find more acceptance than a pure human rights-based approach.

In doing so, African institutions may even be at the forefront of the contemporary debate that accords a central role to human rights as part of global constitutional law and a grundnorm for other international legal regimes. ${ }^{90}$ Unlike a direct application of international humanitarian law, the interpretive approach retains this foundational role of human rights. In doing so, it also avoids further contributing to what has been described as the 'fragmentation' of international law. ${ }^{91}$ The constitutional role of international human rights is not challenged by the fact that they may mean different things in different situations. Their expansion to cover ever newer fields of life and ever newer questions has made it inevitable that they be flexible and adapted to new challenges and situations. One size

89 See eg L Nathan 'The disbanding of the SADC tribunal: A cautionary tale' (2013) 35 Human Rights Quarterly 870; E de Wet 'The rise and fall of the tribunal of the Southern African Development Community: Implications for dispute settlement in Southern Africa' (2013) 28 ICSID Review 45.

90 See eg J Klabbers et al (eds) The constitutionalisation of international law (2009).

91 See Report of the Study Group of the International Law Commission, finalised by $M$ Koskenniemi 'Fragmentation of international law: Difficulties arising from the diversification and expansion of international law' A/CN.4/L.682, 13 April 2006; more specifically with regard to the relationship of human rights and international humanitarian law, see A Orakhelashvili 'The interaction between human rights and humanitarian law: Fragmentation, conflict, parallelism, or convergence?' (2008) 19 European Journal of International Law 161. 
has never fit all, and today 'all' has become an even wider circle than it used to be. 